\title{
The changing sizes of critically endangered white-backed vulture breeding colonies around Kimberley, South Africa
}

Article

Accepted Version

Murn, C., Botha, A. and Wilson, B. (2017) The changing sizes of critically endangered white-backed vulture breeding colonies around Kimberley, South Africa. African Journal of Wildlife Research, 47 (2). pp. 144-148. ISSN 2410-7220 doi: https://doi.org/10.3957/056.047.0144 Available at https://centaur.reading.ac.uk/81222/

It is advisable to refer to the publisher's version if you intend to cite from the work. See Guidance on citing.

To link to this article DOI: http://dx.doi.org/10.3957/056.047.0144

Publisher: BioOne

All outputs in CentAUR are protected by Intellectual Property Rights law, including copyright law. Copyright and IPR is retained by the creators or other copyright holders. Terms and conditions for use of this material are defined in the End User Agreement. 


\section{CentAUR}

Central Archive at the University of Reading

Reading's research outputs online 


\section{The changing sizes of Critically Endangered White-backed Vulture}

2 breeding colonies around Kimberley, South Africa

4 Campbell Murn ${ }^{1,4}$, André Botha ${ }^{2}$ and Beryl Wilson ${ }^{3}$

$6 \quad{ }^{1}$ Hawk Conservancy Trust, Andover, Hampshire, SP11 8DY, England

$7 \quad{ }^{2}$ Endangered Wildlife Trust, Private Bag X11, Modderfontein, 1645, Gauteng, South Africa

$8 \quad{ }^{3}$ Zoology Department, McGregor Museum, P.O. Box 316, Kimberley, 8300 South Africa

$9 \quad{ }^{4}$ School of Biological Sciences, University of Reading, Berkshire, RG6 6AS, England 10

*Corresponding author: campbell@ hawkconservancy.org

\section{Introduction}

The White-backed Vulture (Gyps africanus; WbV) is critically endangered (BirdLife International 2017) and has declined by up to $90 \%$ across parts of its range over the last 30 years (Ogada et al. 2016). It is a tree-nesting species that tends to congregate in groups for breeding (Mundy, Butchart, Ledger \& Piper 1992) and aerial surveys of these breeding areas offer a reliable and repeatable means of assessing local population changes (Howells \& Hustler 1984) that can complement results from road transect surveys (Herremans \& Herremans-Tonnoeyr 2000).

Near Kimberley in central South Africa, breeding WbVs have been at least partially monitored since the 1960s (Forrester 1967). The only aerial survey of this population in 2001 yielded an estimated breeding population of 240 pairs (Murn, Anderson \& Anthony 2002) across six colonies. The 2001 estimate was more than double the previous estimate of 110 pairs (Anderson \& Maritz 1997); at that time, the breeding colonies at Kimberley represented nearly $7 \%$ of the national population estimate of 3,500 pairs (Anderson 2000). Since 2001, however, the population status of all the breeding colonies of WbVs near Kimberley is unknown.

There are no published studies that describe trends longer than 10 years for $\mathrm{WbV}$ populations in South Africa. Numbers of breeding WbVs appear to have declined in some areas (Murn et 
al. 2013) but increased in others (Hitchins 1980; Bamford et al. 2009). Thus, there is a need for long-term (> 10 years) data to assess population trends of endangered vultures. Here we present results from aerial surveys of the WbV breeding colonies at Kimberley in 2014 and compare the results to those from 2001.

\section{Methods}

\section{Study area}

The vulture breeding colonies occur across an area of approximately $4,000 \mathrm{~km}^{2}$ (from S28.50 E24.08 to S29.16 E25.00) around Kimberley in central South Africa (Figure 1). WbVs use camel thorn (Vachellia erioloba) and umbrella thorn (Vachellia tortilis) for nesting (Mundy 1982; Murn \& Anderson 2008), although there are cases of WbVs nesting on powerlines (Anderson \& Hohne 2007).

\section{Aerial survey}

Colonies were surveyed in July when most birds are at their nests, following a peak egglaying period in late May (Anderson 2000a). Before June/July, vultures around Kimberley can still be preparing for nesting and from late July some early-breeding birds may have already hatched and lost chicks (Murn et al. 2002), which results in fewer vultures being seen at their nests.

A Robinson R66 Turbine helicopter was used to survey the six vulture breeding colonies. Pre-survey flight paths were created that traversed the same, or slightly larger, areas than the 2001 survey. Survey flights were conducted with a pilot and two observers at an altitude of 80-120 m a.g.l. (above ground level); airspeed was maintained between $120-140 \mathrm{~km} / \mathrm{h}$. All flights were completed between $09 \mathrm{~h} 00$ and $16 \mathrm{~h} 30$ during conditions of good visibility. The maximum distance between transects was limited to $1000 \mathrm{~m}$ (500 m either side of the helicopter).

Nest positions and flight routes were logged with a GPS and a PDA/Smartphone running CyberTracker (http://cybertracker.org). A nest was recorded as active if it contained an adult in an incubating posture, a nestling, an egg or egg remains. Inactive nests were recorded separately. 
Analysis

Despite optimum survey timing, a small but unknown number of breeding attempts will still remain unrecorded or nests known from the ground will be missed during the aerial survey. To account for this, a correction factor was applied to the aerial survey counts, which was calculated as the difference between the aerial survey count (227) in 2001 and the combined aerial and ground count of all active nests recorded in 2001 (244) (Murn et al. 2002). The correction factor we used was $1.075(244 / 227)$.

76

In both 2001 and 2014, colony areas were determined as minimum convex polygons (MCP). For each colony, the most dispersed nests were used as the MCP points. Density (nests $\mathrm{km}^{-2}$ ) was calculated as the number of nests occurring within the MCP divided by its area.

\section{Results}

82

A total of 165 active nests was recorded across all six colonies, compared with 227 in 2001 breeding population across the six colonies to be approximately 177 pairs (165 x 1.075). The total of all WbV nests (both active and inactive) counted was 219. Across all six colonies, fewer (26\%) nests were estimated compared with the 2001 estimate of 240 nests.

Although nest density decreased at colonies that had reduced in numbers of nests since 2001, average density across all extant colonies was 1.66 nests $\mathrm{km}^{-2}$, more than three times higher than the average nest density across all colonies in $2001\left(0.46\right.$ nests $\left.\mathrm{km}^{-2}\right)$.

\section{Discussion}

\section{Breeding colony numbers}

Since 2001, the number of $\mathrm{WbV}$ nests across the six breeding colonies around Kimberley has decreased. One potential explanation for this change is that the birds have moved; investigations are needed across a wider area to determine if new colonies have been established.

However, the Dronfield colony increased by over 50\% between 1993 and 2014 (A. Anthony, 
personal communication); from 2001 to 2014 there was a smaller increase. Regardless of the reasons for its growth, if the Dronfield colony had been used as an indicator for the

104 Kimberley $\mathrm{WbV}$ breeding population overall, it would have been an inaccurate reflection of the local trend, which was spatially variable and downwards overall.

107 The increase of the Secretarius colony from two to 25 nests and the concomitant 108 disappearance of nearly the same number of nests from the Paardeburg colony makes it tempting to assume that the birds moved from one location to the other, but these colonies changing in number by similar amounts is likely to be coincidental. In 2001, the colony at

111 Paardeburg had grown from three to 27 pairs over the preceding five years (D. Du Toit, farm

112 owner, personal communication), whilst the two nests and embryonic colony at Secretarius

113 had just re-established. At the time, nest densities at these two colonies were lower than the

114 other colonies and studies highlighted that sufficient food existed for the birds (Murn \&

115 Anderson 2008); factors supporting a conclusion that the $\mathrm{WbV}$ breeding population around

116 Kimberley was growing (Murn et al. 2002). It now appears to have decreased. Land use

117 change offers a potential explanation. For example, the development of a mining operation

118 near the Paardeburg colony and land ownership/tenancy changes at the Rivermead colony

119 may be reasons for breeding birds moving away. Conversely, at the Dronfield colony, there

120 has been stable land management over recent decades and the site is a proclaimed nature

121 reserve. These differences in setting for each of the colonies and the potential for breeding

122 birds to move highlights the need for surveys across a wide area and also coordination

123 between fieldworkers at different sites.

125 If the results across the surveyed colonies are representative of a decline in the number of

126 breeding vultures, there are implications for other parts of southern Africa. It is possible that

127 other breeding populations of $\mathrm{WbVs}$ have undergone significant change over the same

128 period. For example, the current red data book account for WbVs (Allan 2015) highlights the

129 'uneven coverage and outdated nature of some estimates' ( $p$ 63) and by necessity reports

130 population figures and estimates that are 10 or more years old. There is clearly a need for

131 updated breeding population estimates to be published from a variety of survey efforts across

132 southern Africa.

134 Threats to vultures

135 Electrocution by powerlines and drowning in farm reservoirs are important causes of 
mortality for vultures in the Kimberley area (Anderson \& Kruger 1995; Anderson 2000b) and elsewhere (van Rooyen 2000), but compared to other areas where poisoning kills large numbers of vultures, the severity of these threats is relatively low. For example, poisonrelated mortalities have occurred historically (van Jaarsveld 1987) and remain a continuing

140 threat to vultures in Kruger National Park (Murn \& Botha 2017) and other parts of southern

141 Africa (Ogada, Botha \& Shaw 2015). The absence of a poisoning threat and a positive opinion of vultures amongst landowners (Murn \& Anderson 2008), makes the Kimberley area an important breeding site for $\mathrm{WbVs}$ in southern Africa. However, various threats such as land use change from diamond mining and tree clearance for agriculture adjacent to Mokala colony, unsafe electrical powerlines and the development of concentrated solar thermal power (CSP) plants remain.

WbVs move across large areas that can consist of several countries (Phipps, Willis, Wolter \& Naidoo 2013) and some of these countries have seen high poisoning rates that have resulted in vulture populations being reduced (Roxburgh \& McDougall 2012) or where large numbers of vultures continue to be killed (Groom, Gandiwa, Gandiwa \& van der Westhuizen 2013). Vultures from the Kimberley area travel as far as Namibia (authors' unpublished data); at least two birds from Kimberley died in the Caprivi Strip in Namibia, where approximately 500 birds were poisoned (Hartman 2013). Many of the birds killed at poisoning events are breeding adults and, as a result, we speculate that any local declines may be due in part to increased mortality of vultures in other regions that are far from Kimberley.

\section{Recommendations}

159 Continued monitoring of the Kimberley $\mathrm{WbV}$ breeding population is essential because it is

160 important regionally and may reflect vulture mortality elsewhere. In addition, monitoring

161 changes in breeding populations across southern Africa is fundamental for coordinating 162 conservation management efforts. A better understanding of the ranging patterns of adult

$163 \mathrm{WbVs}$ throughout the year is important because wide-ranging birds like vultures are exposed 164 to a variety of threats and the severity of this exposure for non-breeding adults is currently unknown for WbVs. Finally, there are no published road transect data for the Kimberley and surrounding areas. Such data would provide a valuable complement to survey data focused on numbers of nests and should therefore be a research priority.

\section{Acknowledgements}


171 We are very grateful to pilot Peter Hohne (The Bateleurs), Ronelle Visagie, International

Vulture Programme partners, Eskom, SANParks (Mokala National Park) and local

173 landowners in particular De Beers. The manuscript was improved by comments from Mark Anderson, Angus Anthony and two reviewers.

Allan, D.G. (2015). White-backed Vulture Gyps africanus. In M.R. Taylor, F. Peacock \& R.M. Wanless (Eds), The 2015 Eskom Red Data book of birds of South Africa, Lesotho and Swaziland (pp. 61-66). Johannesburg: BirdLife South Africa.

Anderson, M.D. (2000a). African Whitebacked Vulture. In K.N. Barnes (Ed.), The Eskom Red Data Book of birds of South Africa, Lesotho and Swaziland (pp. 75-77). Johannesburg: BirdLife South Africa.

Anderson, M.D. (2000b) Raptor conservation in the northern Cape Province, South Africa. Ostrich, 71, 25-32.

Anderson, M.D. \& Hohne, P. (2007) African White-backed Vultures nesting on electricity pylons in the Kimberley area, Northern Cape and Free State Provinces, South Africa. Vulture News, 57, 44-50.

Anderson, M.D. \& Kruger, R. (1995) Power line electrocution of eighteen African Whitebacked Vultures. Vulture News, 32, 16-18.

Anderson, M.D. \& Maritz, A.W.A. (1997). The status and distribution of vultures in the Northern Cape Province, South Africa. In A.F. Boshoff, M.D. Anderson \& W.D. Borello (Eds), Vultures in the 21st Century (pp. 37-45). Johannesburg: Vulture Study Group.

Bamford, A.J., Monadjem, A., Anderson, M.D., Anthony, A., Borello, W.D., Bridgeford, M., Bridgeford, P., Hancock, P., Howells, W.W., Wakelin, J. \& Hardy, I.C.W. (2009) Trade-offs between specificity and regional generality in habitat association models: a case study of two species of African vulture. Journal of Applied Ecology, 46, 852860.

BirdLife (2017). BirdLife/IUCN Red List for Birds. Retrieved from: www.birdlife.org on 1st May 2017

Forrester, A.K. (1967) Some observations made on white-backed vultures (Gyps africanus) while nesting. Bokmakierie, 19, 6-8.

Groom, R.J., Gandiwa, E., Gandiwa, P. \& van der Westhuizen, H.J. (2013) A mass poisoning of White-backed and Lappet-faced vultures in Gonarezhou National Park. Honeyguide, 59, 5-9.

Hartman, A. (2013). 500 birds poisoned. Retrieved from: http://www.namibian.com.na/index.php?page $=\operatorname{archive-read\& id=112821}$ on $01 / 11 / 2016$

Herremans, M. \& Herremans-Tonnoeyr, D. (2000) Land use and the conservation status of raptors in Botswana. Biological Conservation, 94, 31-41.

Hitchins, P.M. (1980) Breeding populations of vultures in the Hluhluwe-Umfolozi game reserve complex. Lammergeyer, 30, 26-31.

Howells, W.W. \& Hustler, K. (1984) The status and breeding success of eagles and vultures in the Hwange National Park, Zimbabwe. Durban: Natal Bird Club. 
Mundy, P., Butchart, D., Ledger, J. \& Piper, S. (1992) The Vultures of Africa. London: Academic Press.

Mundy, P.J. (1982) The comparative biology of southern African vultures. Johannesburg: Vulture Study Group.

Murn, C. \& Anderson, M.D. (2008) Activity patterns of African White-backed Vultures Gyps africanus in relation to different land-use practices and food availability. Ostrich, 79, 191-198.

Murn, C., Anderson, M.D. \& Anthony, A. (2002) Aerial survey of African white-backed vulture colonies around Kimberley, Northern Cape and Free State provinces, South Africa. South African Journal of Wildlife Research, 32, 145-152.

Murn, C. \& Botha, A. (2017) A clear and present danger: impacts of poisoning on a vulture population and the effect of poison response activities. Oryx, 1-7.

Murn, C., Combrink, L., Ronaldson, G.S., Thompson, C. \& Botha, A. (2013) Population estimates of three vulture species in Kruger National Park, South Africa. Ostrich, 84, $1-9$.

Ogada, D.L., Botha, A. \& Shaw, P. (2015) Ivory poachers and poison: drivers of Africa's declining vulture populations. Oryx, doi 10.1017/S0030605315001209.

Ogada, D.L., Shaw, P., Beyers, R.L., Buij, R., Murn, C., Thiollay, J.M., Beale, C.M., Holdo, R.M., Pomeroy, D., Baker, N., Krüger, S.C., Botha, A., Virani, M.Z., Monadjem, A. \& Sinclair, A.R.E. (2016) Another continental vulture crisis: Africa's vultures collapsing toward extinction. Conservation Letters, 9, 89-97.

Phipps, W.L., Willis, S.G., Wolter, K. \& Naidoo, V. (2013) Foraging ranges of immature African White-backed Vultures (Gyps africanus) and their use of protected areas in southern Africa. PLoS ONE, 81, e52813.

Roxburgh, L. \& McDougall, R. (2012) Vulture poisoning incidents and the status of vultures in Zambia and Malawi. Vulture News, 62, 33-39.

van Jaarsveld, J. (1987) Increasing numbers of vultures poisoned in the Kruger National Park. Vulture News, 18, 18-21.

van Rooyen, C.S. (2000) An overview of vulture electrocutions in South Africa. Vulture News, 43, 5-22. 
251 Table 1: Aerial survey counts of six White-backed Vulture breeding colonies near Kimberley, South 252 Africa, between 2001 and 2014

\begin{tabular}{lccccc}
\hline Colony name & Aerial survey count & \% change & Area $\left(\mathrm{km}^{2}\right) /$ density $\left(\right.$ nests $\left.\mathrm{km}^{-1}\right)$ \\
\hline Dronfield & 2001 & 2014 & & 2001 & 2014 \\
\hline Mokala & 69 & 74 & $+264 \%$ & $135 / 0.32$ & $162 / 0.46$ \\
\hline Rivermead & 24 & 55 & $-20 \%$ & $120 / 0.58$ & $134 / 0.41$ \\
\hline Susanna & 79 & 9 & $-79 \%$ & $50 / 0.48$ & $1.6 / 3.12$ \\
\hline Paardeburg & 27 & 0 & $-100 \%$ & $66 / 0.41$ & $55 / 0.16$ \\
\hline Secretarius & $\mathrm{ns}(2)^{\#}$ & 25 & $+1250 \%$ & $5 / 0.4$ & $5.8 / 4.14$ \\
\hline Total & $\mathbf{2 2 7}$ & $\mathbf{1 6 7}$ & $\mathbf{- 2 6 \%}$ & - & - \\
\hline
\end{tabular}

253 *Aerial survey count lower than ground survey count (48) conducted in 2001

254 \#Not surveyed by air in 2001; two nests found during ground surveys 
258 Captions for Figure:

259

260 Figure 1: Location of six White-backed Vulture breeding colonies around Kimberley, South 261 Africa.

262

263 


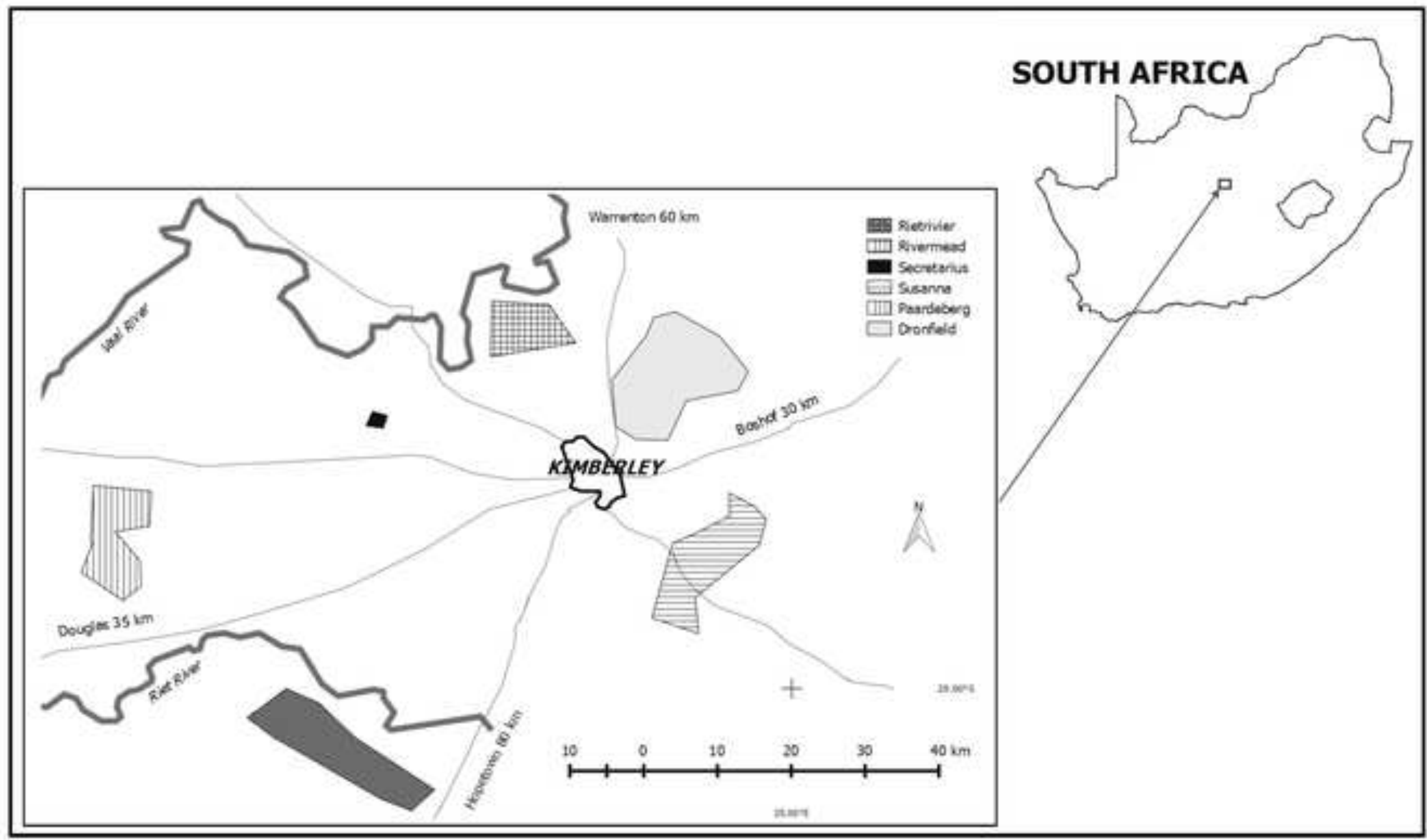

